\title{
Cultura neoliberal: leis de incentivo como política pública de cultura
}

Rafael Pereira Oliveira ${ }^{1}$

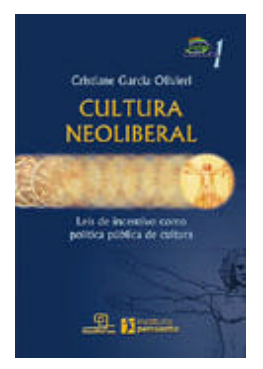

OLIVIERI, Cristiane Garcia. Cultura neoliberal: leis de incentivo como política pública de cultura. São Paulo: Escrituras, 2004. 206p.

A partir dos anos 1990, a expressão "economia da cultura" passou a ser recorrente no discurso oficial sobre gestão cultural, no Brasil. Se, por um lado, a valorização da cadeia produtiva da cultura deu nova dimensão ao investimento no setor, por outro, a cultura passou a ser interpretada primordialmente pela ótica da racionalidade instrumental. Além disso, com a justificativa da eficiência, atividades socioculturais que até então eram de responsabilidade pública foram transferidas para o terceiro setor ou compartilhadas com a iniciativa privada. Nesse contexto, em 1998, o Ministério da Cultura encomendou à Fundação João Pinheiro uma série de pesquisas com o objetivo de avaliar o impacto dos investimentos públicos e privados em cultura no Brasil. Esses estudos passaram a ser, desde então, as principais referências de informações sobre a economia da cultura no país. No entanto, os bancos de dados da cultura ainda carecem de uma reflexão crítica sobre seus números. O livro de Cristiane Olivieri ajuda a atenuar essa carência.

Cultura neoliberal, que faz parte da coleção "Visões da cultura", ${ }^{2}$ do Instituto Pensarte, é baseado na dissertação de mestrado da autora, defendida na Escola de Comunicação e Artes da Universidade de São Paulo (ECA-USP). Numa linguagem objetiva, Olivieri descreve o comportamento do poder público brasileiro com relação à cultura, desde o lançamento da primeira lei baseada em incentivos fiscais. Aponta os prós e os contras da gestão cultural alinhada com o ideal neoliberal e mostra as diferenças entre mecanismo de financiamento e políticas públicas.

O livro apresenta uma visão crítica da gestão pública da cultura no Brasil e promove uma comparação com a política cultural norte-americana. Os méritos de Cristiane estão na clareza com que desenvolve o tema e, principalmente, no posicionamento a favor da cultura. Sem negar a importância do mercado, a autora defende que uma política cultural pública deve privilegiar a lógica do agir cultural sobre todas as outras. E é com esse posicionamento crítico que vai construindo seu texto.

Nos dois primeiros capítulos, descreve as fontes de financiamento da cultura disponíveis no Brasil e suas influências nas produções culturais e apresenta as bases do que considera uma política pública para a cultura. Completa sua reflexão fazendo uma comparação crítica do sistema brasileiro com o modelo americano de gestão, escolhido por basear-se, também, tanto em benefícios fiscais, quanto no sistema de fundo direto.

No capítulo três, analisa a lógica dos mecanismos de mecenato e fundo direto e a importância que eles vão obtendo no contexto da gestão pública da cultura no país, ressaltando aspectos que estão em desacordo com a

\footnotetext{
${ }^{1}$ Mestrando em administração pelo CPGA/UFSC, membro do Observatório da Realidade Organizacional e professor das Faculdades Energia de Administração e Negócios. Endereço: Observatório da Realidade Organizacional - Centro Socioeconômico - UFSC. Campus Universitário - Trindade. Caixa Postal 476 - Florianópolis, SC - CEP: 88.040-900. E-mail: rafaelpo@ floripa.com.br.

${ }^{2}$ A coleção "Visões da cultura" conta ainda com as publicações Projetos culturais, de Fábio Cesnik e Maria Eugênia Malagoni, e Mercado cultural, de Leonardo Brant.
} 
lógica do fazer artístico. No quarto capítulo, apresenta os dados referentes à Lei Rouanet, no período 19962000, apontando os principais problemas na utilização dessa lei como fomentadora da produção cultural brasileira.

As reflexões de Olivieri no capítulo cinco e na conclusão do livro constatam que o mecenato tornou-se a principal ação do período FHC na área da cultura, substituindo a formulação de uma política cultural mais ampla e mostrando-se incapaz de fomentar a cultura em toda a sua diversidade. A autora aponta para a urgência de se delimitar a atuação das leis, ressaltando suas qualidades e evidenciando suas deficiências para assumir o caráter central das políticas públicas para a cultura.

Ler Cultura neoliberal à luz do final de um governo que se elegeu em contraposição ao período analisado no livro, mostra o quanto atual e urgente é esse debate. O governo Lula iniciou a construção das bases de um novo modelo de gestão pública para a cultura, mas a timidez com que interveio na relação cultura/Estado/mercado reforça a necessidade de se avançar nas discussões elaboradas por Olivieri. 